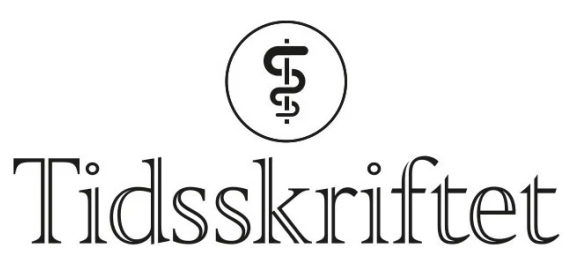

DEN NORSKE LEGEFORENING

\title{
Fødende risikopasient med covid-19
}

\author{
KORT KASUISTIKK
}

ANE CECILIE MUNK

acmunk@lyse.net

Forskningsavdelingen

Sørlandet sykehus, Kristiansand

og

Kvinneklinikken

Sørlandet sykehus, Kristiansand

Ane Cecilie Munk er ph.d., spesialist i fødselshjelp og kvinnesykdommer, postdok og overlege.

Forfatteren har fylt ut ICMJE-skjemaet og oppgir ingen interessekonflikter.

\section{LINDA REME SAGEDAL}

Forskningsavdelingen

Sørlandet sykehus, Kristiansand

og

Kvinneklinikken

Sørlandet sykehus, Kristiansand

Linda Reme Sagedal er ph.d., spesialist i fødselshjelp og kvinnesykdommer, overlege og forsker.

Forfatteren har fylt ut ICMJE-skjemaet og oppgir ingen interessekonflikter.

\section{TURID STAVSETH KROGEDAL}

Fødeavdelingen

Kvinneklinikken

Sørlandet sykehus, Kristiansand

Turid Stavseth Krogedal er jordmor.

Forfatteren har fylt ut ICMJE-skjemaet og oppgir ingen interessekonflikter.

\section{IDA MCFADZEAN}

Kvinneklinikken

Sørlandet sykehus, Kristiansand

Ida McFadzean er spesialist i allmennmedisin og lege i spesialisering i fødselshjelp og

kvinnesykdommer.

Forfatteren har fylt ut ICMJE-skjemaet og oppgir ingen interessekonflikter.

\section{HANNA OOMMEN}

Fødeavdelingen

Kvinneklinikken

Sørlandet sykehus, Kristiansand

Hanna Oommen er fagutviklingsjordmor.

Forfatteren har fylt ut ICMJE-skjemaet og oppgir ingen interessekonflikter. 


\section{Vi presenterer her pasientforløpet til en tvillinggravid kvinne som fikk påvist sars-CoV-2-infeksjon kort tid før fødselen.}

En tvillinggravid, flergangsfødende kvinne i zo-årene ble innlagt tidlig i april 2020 for fødselsinduksjon med ballongkateter og misoprostol i svangerskapsuke 38 på grunn av usikker korionisitet. Svangerskapet hadde vært ukomplisert og med jevn tilvekst. Tvilling 1 lå i hodeleie og tvilling 2 i seteleie. Kvinnen hadde ingen symptomer på covid-19 ved innkomst.

Tredje induksjonsdag fikk hun sår hals uten feber. Isolasjon med dråpesmitteregime (1) ble innført. Hun testet positivt for sars-CoV-2. Grunnet behov for tett obstetrisk oppfølging, fortsatte induksjonsforløpet på fødestue tilrettelagt for covid-19-pasienter. Pasientens mann fikk være til stede.

På grunn av tegn til føtalt distress hos tvilling 1 ble det samme kveld utført amniotomi med anleggelse av STAN (intern kardiotokografi (CTG) med ST-analyse) for tettere overvåkning. Begynnende korioamnionitt kunne ikke utelukkes, og penicillin ble gitt intravenøst. Det var forbigående patologisk CTG og STAN med dårlig signalkvalitet, og skalplaktat hos fosteret var 2,8 mmol/l (referanseområde $<4,2 \mathrm{mmol} / \mathrm{l}$ ). Det ble gitt tokolyse (atosiban) og væske intravenøst samt gjennomført stillingsendring. CTG ble normalisert, og

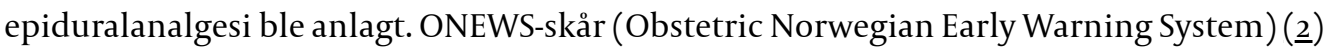
målt en gang i timen var overveiende normal, bortsett fra takykardi rundt $100 \mathrm{slag} / \mathrm{min}$. Før aktiv fødsel hadde pasienten fall i $\mathrm{SaO}_{2}$ til $92 \%(\geq 95 \%)$, men dette ble normalisert med $\mathrm{O}_{2}$ på nesekateter (1-2 l/min). Under fødselen hadde hun kun lett tørrhoste og ikke lenger behov for oksygenbehandling.

Etter syv timer i aktiv fødsel ble oksytocinstimulering startet. Ved full åpning fant man patologisk fosterlyd hos tvilling 1 og lett takykardi hos tvilling 2 . Tvilling 1 ble forløst med vakuum på indikasjonen truende asfyksi. Apgarscore var 9-10-10 og pH i umbilikalarterien 7,2 (7,05-7,38). Tvilling 2 hadde bradykardi (<8o slag/min, > 3 min) og ble seks minutter senere forløst med uttrekning på fot. Apgarscore var 7-9-10 og pH 7,18.

Mor og barn ble flyttet til covid-19-posten ved medisinsk avdeling med post partumomsorg av barselpersonell. Kvinnen var preget av asteni, men hadde ellers ingen uttalte symptomer. Penicillin ble kontinuert som profylakse under innleggelsen. Hun ble utskrevet til hjemmet tre dager etter fødselen. Tvillingene var friske under hele forløpet, og kvinnen ble symptomfri ti dager etter fødselen. Pasientens mann og eldre barn hadde også symptomer fra øvre luftveier, men tilfredsstilte ikke kriteriene for sars-CoV-2-testing på daværende tidspunkt. 14 sykehusansatte ble ilagt to ukers karantene grunnet kontakt med pasienten. Ingen av dem fikk påvist smitte.

\section{Diskusjon}

Som de fleste med covid-19 har også majoriteten av gravide milde symptomer $(3,4, \underline{6})$. I en metaanalyse var sår hals en uvanlig presentasjon (5/35), mens feber (48\%) og tørrhoste (46\%) var hyppigere (7.). I en undersøkelse fra fødeavdelinger i New York var det flere fødekvinner som utviklet symptomer etter innleggelse (3). Kvinner innlagt under svangerskap og fødsel kommer vanligvis i kontakt med mange sykehusansatte. Vi mener derfor at lav terskel for isolering og testing er nødvendig for å unngå smittespredning.

Det er viktig å unngå unødvendige keisersnitt. Gjennomgang av de første publiserte tilfellene med covid-19 i svangerskapet viser at 46 av 48 ble forløst med sectio caesarea uten at indikasjonen ble beskrevet (7.). Det kan spekuleres på hvorvidt pasientbehandlingen $\mathrm{i}$ tidlig fase ble påvirket av erfaringer fra andre pandemier. Eksempelvis har koronavirusinfeksjoner som sars-CoV og mers-CoV betydelig høyere maternell morbiditet (4). Sectio kan også ha blitt valgt for å redusere smitterisikoen til barnet, da man har sett at 
zika- og hivvirus kan overføres fra mor til foster under graviditet og fødsel (5). Norge har lav sectiofrekvens sammenlignet med andre land, og pandemien kom senere til landet. Dermed kunne vi lære av andres rapporterte erfaringer. Norsk gynekologisk forening og WHO anbefaler vaginal forløsning for covid-19-pasienter; sectio skal utføres på maternell eller obstetrisk indikasjon (1).

Sannsynligvis har gravide med covid-19 økt risiko for preterm vannavgang, preterm fødsel og tegn på føtalt distress (7,요). Det er så langt ikke påvist sars-CoV-2 i vaginalsekret, og undersøkelser av nyfødte i en stor britisk registerstudie bekrefter at det er sjeldent med smitte før eller under fødselen (4.). Den norske veilederen anbefaler kontinuerlig CTGregistrering under fødsel. Det anses som trygt å bruke intern CTG-registrering og skalplaktatmåling for å sikre god overvåking (1). Norsk barnelegeforening, WHO og Folkehelseinstituttet anbefaler at asymptomatiske, nyfødte barn isoleres sammen med sin sars-CoV-2-positive mor, med mindre hun er alvorlig syk $(9, \underline{10})$.

Gode forberedelser er avgjørende for å sikre forsvarlig behandling og for å minimere smitterisiko (무, 11). I mangel av fødestuer med sluse har vi dedikert én av fem fødestuer og to pasientrom til covid-19-pasienter. I tillegg er et eget asfyksirom for smittede opprettet.

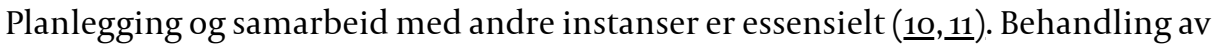
pasienten i denne kasuistikken krevde samarbeid mellom fødeavdeling, medisinsk avdeling, anestesi-/operasjonsavdeling og barneavdeling. For å trygge akuttkommunikasjon med barneavdeling og anestesi-/operasjonsavdeling har fødeavdelingen installert egne alarmknapper for covid-19-pasienter. Elektronisk overføring av CTG/STAN-registrering og telefonkontakt med jordmor muliggjør tett oppfølging tross isoleringstiltak. Fødeteamet opplevde god kommunikasjon og drøfting av akutte scenarioer som grunnleggende for å kunne følge smittevernprosedyrer under fødselen.

Forsvarlig pasientbehandling under en pandemi krever målrettet opplæring av

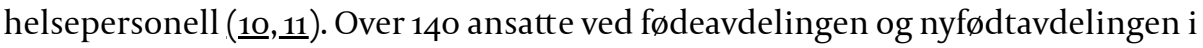
Kristiansand hadde tidlig i koronakrisen gjennomgått teoretisk og praktisk opplæring i smittevernprosedyrer. Flytskjemaer, prosedyrer, opplæringsfilm og informasjonsmapper ble utarbeidet. I ettertid har flere gitt uttrykk for at dette ga trygghet i en presset situasjon.

Pasienten og barnefar har gitt samtykke til at artikkelen blir publisert.

Artikkelen er fagfellevurdert.

\section{LITTERATUR}

1. Findal G, Greve-Isdahl M, Sitras V et al. Koronavirus ved svangerskap og fødsel. Veileder i fødselshjelp. Versjon 3. https://www.legeforeningen.no/foreningsledd/fagmed/norsk-gynekologiskforening/veiledere/ Lest 24.6.2020.

2. Øverland EA, Ellingsen L, Heide HC et al. ONEWS: Obstetric Norwegian Early Warning Score System. Veileder i fødselshjelp, 17.2.2020.

3. Breslin N, Baptiste C, Gyamfi-Bannerman C et al. COVID-19 infection among asymptomatic and symptomatic pregnant women: Two weeks of confirmed presentations to an affiliated pair of New York City hospitals. Am J Obstet Gynecol MFM 2020; 2: 100118. [PubMed][CrossRef]

4. Knight M, Bunch K, Vousden N et al. Characteristics and outcomes of pregnant women admitted to hospital with confirmed SARS-CoV-2 infection in UK: national population based cohort study. BMJ 2020;369: m2107. [PubMed][CrossRef]

5. Arora N, Sadovsky Y, Dermody TS et al. Microbial vertical transmission during human pregnancy. Cell Host Microbe 2017; 21: 561-7. [PubMed][CrossRef]

6. Wu Z, McGoogan JM. Characteristics of and important lessons from the coronavirus disease 2019 (COVID-19) outbreak in China: Summary of a report of 72314 cases from the Chinese Center for Disease Control and Prevention. JAMA 2020; 323: 1239-42. [PubMed][CrossRef]

7. Della Gatta AN, Rizzo R, Pilu G et al. Coronavirus disease 2019 during pregnancy: a systematic review of reported cases. Am J Obstet Gynecol 2020; 223:36-41. [PubMed][CrossRef] 
8. Liu Y, Chen H, Tang K et al. Clinical manifestations and outcome of SARS-CoV-2 infection during pregnancy. J Infect 2020; So163-4453(20)30109-2. [PubMed][CrossRef]

9. Lang AK, Klinkenberg C, Greve-Isdahl M et al. Rutiner for håndtering av barn av fødekvinner med påvist/mulig Covid-19 infeksjon V-3.1. Norsk Barnelegeforening.

https://www.legeforeningen.no/contentassets/7fe2786b43cb44a9azaffe4a8f944d75/20200330_covid19_ fode_nyfodt_v3.1.pdf Lest 24.6.2020.

10. Hospital Preparedness for Epidemics. Geneva: WHO Press, 2014.

https://www.who.int/publications/i/item/hospital-preparedness-for-epidemics Lest 24.6.2020.

11. Helse Sør- Øst. Regional beredskapsplan for pandemi og alvorlig smittsom sykdom. Delplan til Regional Beredskapsplan og Regional Smittevernplan. https://www.helse-sorost.no/beredskap Lest 24.6.2020.

Publisert: 16. juli 2020. Tidsskr Nor Legeforen. DOI: 10.4045/tidsskr.20.0425

Mottatt 11.5.2020, første revisjon innsendt 5.6.2020, godkjent 24.6.2020.

Publisert under åpen tilgang CC BY-ND. Lastet ned fra tidsskriftet.no 26. april 2023. 